\title{
PENGARUH KUALITAS PELAYANAN TERHADAP KEPUASAN DAN LOYALITAS PASIEN RAWAT INAP DI RSU ASSALAM GEMOLONG SRAGEN
}

\author{
Dwi Wahyuti \\ Budi Poniman \\ STIE AUB SURAKARTA
}

\begin{abstract}
Abstrak
Penelitian ini bertujuan untuk mengetahui dan memberikan bukti bahwa: 1) Reliability berpengaruh terhadap kepuasan pasien rawat inap di RSU Assalam Gemolong Sragen, 2) Responsiveness berpengaruh terhadap kepuasan pasien rawat inap di RSU Assalam Gemolong Sragen, 3) Assurance berpengaruh terhadap kepuasan pasien rawat inap di RSU Assalam Gemolong Sragen, 4) Tangibles berpengaruh terhadap kepuasan pasien rawat inap di RSU Assalam Gemolong Sragen, 5) Empathy berpengaruh terhadap kepuasan pasien rawat inap di RSU Assalam Gemolong Sragen, 6) Reliability berpengaruh terhadap loyalitas pasien rawat inap di RSU Assalam Gemolong Sragen, 7) Responsiveness berpengaruh terhadap loyalitas pasien rawat inap di RSU Assalam Gemolong Sragen, 8) Assurance berpengaruh terhadap loyalitas pasien rawat inap di RSU Assalam Gemolong Sragen, 9) Tangibles berpengaruh terhadap loyalitas pasien rawat inap di RSU Assalam Gemolong Sragen, 10) Empathy berpengaruh terhadap loyalitas pasien rawat inap di RSU Assalam Gemolong Sragen, 11) Kepuasan berpengaruh terhadap loyalitas pasien rawat inap di RSU Assalam Gemolong Sragen.

Penelitian ini adalah penelitian survey data yang dikumpulkan sebesar 100 responden sebagai sampel penelitian dari populasi sejumlah 600 pasien rawat inap RSU Assalam Gemolong Sragen. Analisis data dilakukan dengan Uji Linieritas, Analisis Jalur, Uji Hipotesis meliputi Persamaan Regresi, Uji t, Uji F, Analisis Koefisien Determinasi $\left(\mathrm{R}^{2}\right)$, Penaruh Langsung Dan Pengaruh Tidak Langsung dan Analisis Korelasi.

Hasil penelitian ini menunjukkan : 1) Reliability berpengaruh positif dan signifikan terhadap kepuasan pasien rawat inap di RSU Assalam Gemolong Sragen, 2) Responsiveness berpengaruh positif dan signifikan terhadap kepuasan pasien rawat inap di RSU Assalam Gemolong Sragen, 3) Assurance berpengaruh positif dan signifikan terhadap kepuasan pasien rawat inap di RSU Assalam Gemolong Sragen, 4) Tangibles berpengaruh positif dan signifikan terhadap kepuasan pasien rawat inap di RSU Assalam Gemolong Sragen, 5) Empathy berpengaruh positif dan signifikan terhadap kepuasan pasien rawat inap di RSU Assalam Gemolong Sragen, 6) Reliability berpengaruh positif dan signifikan terhadap loyalitas pasien rawat inap di RSU Assalam Gemolong Sragen, 7) Responsiveness berpengaruh positif dan signifikan terhadap loyalitas pasien rawat inap di RSU Assalam Gemolong Sragen, 8) Assurance berpengaruh positif dan signifikan terhadap loyalitas pasien rawat inap di RSU Assalam Gemolong Sragen, 9) Tangibles berpengaruh positif dan signifikan terhadap loyalitas pasien rawat inap di RSU Assalam Gemolong Sragen, 10) Empathy berpengaruh positif dan signifikan terhadap loyalitas pasien rawat inap di RSU Assalam Gemolong Sragen, 11) Kepuasan berpengaruh positif dan signifikan terhadap loyalitas pasien rawat inap di RSU Assalam Gemolong Sragen.

Uji F menunjukkan kelima variabel yaitu reliability, responsieness, assurance, tangibles dan empathy secara bersama-sama berpengaruh positif dan signifikan terhadap kepuasan rawat inap dan nilai signifikansi $0,000<0,05$.

Nilai R Square total sebesar 0,971 berarti loyalitas di jelaskan oleh dimensi kualitas layanan dengan kepuasan sebagai variabel intervening sebesar 97,1\% dan sisanya sebesar 2,9\% dijelaskan oleh variabel lain, misalnya lokasi.

Kata kunci : Kualitas Pelayanan, Kepuasan dan Loyalitas.
\end{abstract}

PENDAHULUAN 
Faktor yang mempengaruhi kualiats pelayanan adalah pelayanan yang diharapkan dan pelayanan yang dirasakan (Parasuraman dalam Tjiptono, 2007: 67). Jika pelayanan diterima seperti dengan harapan pelanggan, maka kualitas pelayanan dipersepsikan baik dan memuaskan pelanggan. Menurut Kotler (2007: 177) bahwa kepuasan konsumen yang dipahami menghasilkan rasa senang dan kecewa jika kinerja memenuhi harapan, maka konsumen puas dan jika tidak memenuhi harapan, maka konsumen merasa tidak puas. Selanjutnya semakin tinggi kualitas pelayanan akan meningkatkan kepuasan konsumen.

Pengukuran kualitas rumah sakit kompleks sifatnya karena pelayanan di rumah sakit dibagi atas pelayanan medis dan non medis. Didalam kulitas medis terdapat keterbatasan yang berhubungan dengan kode etik dan standart pelayanan profesi, secara umum pelayanan rumah sakit terdiri dari perawatan jalan dan rawat inap. Pelayanan rawat inap, merupakan pelayanan medis yang utama di rumah sakit dan merupakan tempat untuk interaksi antara pasien dan rumah sakit berlangsung dalam waktu yang lama. Pelayanan rawat inap melibatkan pasien, perawat, dokter, administrasi, dan petugas lainnya dalam rumah sakit, hubungannya menyangkut kepuasan pasien, mutu pelayanan dan citra rumah sakit.

Pelanggan yang loyal memiliki keuntungan bagi perusahaan, diantaranya konsumen yang loyal terhadap membeli produk perusahaan untuk waktu yang cukup lama dan menyebarkan informasi yang positif tentang produk perusahaan yang ditawarkan (Kotler, 2006: 547).

Penelitian ini didukung oleh penelitian Handayani (2006), hasilnya menunjukkan terdapat pengaruh positif dan signifikan antara variabel tangible, reliability, responsiveness, assurance, dan empathy terhadap kepuasan dan loyalitas nasabah BNI Taplus Kantor Cabang UNAIR Surabaya. Juga didukung oleh penelitian Wasi (2010), hasilnya menunjukkan bahwa lima dimensi kualitas pelayanan yaitu reliability, responsiveness, assurance, tangibles dan empathy mempunyai pengaruh yang positif dan signifikan terhadap kepuasan dan loyalitas nasabah di Asuransi Jiwa Bumi Putra 1912 Kantor Cabang Wonogiri.

Rumah sakit Assalam Gemolong Sragen perlu secara cermat menentukan kebutuhan konsumen sebagai upaya untuk memenuhi keinginan dan meningkatkan kepuasan atas pelayanan yang diberikan. Menjalin hubungan dan melakukan penelitian terhadap mereka perlu dilakukan agar pelayanan yang diberikan sesuai dengan yang diharapkan, untuk mencapai hal tersebut perlu dilakukan evaluasi dari pelanggannya. Kualitas pelayanan jasa meliputi : Reliability, Responsiveness, Empathy, Assurance, dan Tangibles.

Rumah sakit Assalam Gemolong Sragen terletak di Kalurahan Ngembat Padas Gemolong Sragen adalah suatu tempat usaha jasa pelayanan kesehatan dalam memberikan pelayanan yang berkualitas, selalu berorientasi kepada kepuasan pasien serta respek terhadap setiap orang yang datang memberikan pelayanan kerja yang terampil dan profesional. Sebagian besar pasien pelanggan Rumah Sakit Assalam Gemolong adalah warga pedesaan yang ingin mendapatkan pelayanan murah, ramah dan baik, maka Rumah Sakit Assalam Gemolong berusaha terus meningkatkan mutu pelayanan secara berkelanjutan. Dengan melihat perilaku pelanggan dapat untuk mengetahui pengaruh, kualitas pelayanan terhadap kepuasan pelanggan dalam menggunakan jasa Rumah Sakit Assalam Gemolong Sragen.

\section{TINJAUAN PUSTAKA}

\section{Loyalitas}

Menurut Jacoby, et.al., (dalam Oliver, 1997: 392) loyalitas adalah suatu pandangan yang mendalam tentang komitmen pembelian ulang terhadap suatu produk atau jasa secara konsisten. Untuk mengukur loyalitas ada tiga kategori pendekatan menurut Lupiyoadi dan Hamdani 2008: 195 yaitu : 1) Pendekatan perilaku, 2) Pendekatan sikap, dan 3) Pendekatan terintegritas. Indikator loyalitas yang dikemukakan Kadampully et.al. (2000) sebagai berikut : 1) Pemakaian ulang, 2) Merekomendasikan, 3) Menyampaikan hal-hal yang positif, 4) Mempengaruhi, 5) Mempertimbangkan.

\section{Kepuasan}


Menurut Kotler (2007: 177) bahwa kepuasan dimaknai sebagai perasaan senang atau kecewa seseorang yang muncul setelah membandingkan produk yang dirasakan dengan produk yang diharapkan. Kotler (2007: 38) untuk mengukur kepuasan konsumen sebagai berikut : 1) Sistem keluhan dan saran, 2) Survey kepuasan pasien, 3) ghost Shopping, 4) Lost Customer Analisis. Sedangkan menurut Lupiyoadi (2008: 192) dalam menentukan tingkat kepuasan konsumen terdapat lima faktor utama yang harus diperhatikan yaitu 1) Kualitas produk, 2) Kualitas pelayanan, 3) Emosional, 4) Harga, 5) Biaya.

\section{Reliability}

Menurut Parasuraman (2008) mengemukakan bahwa Reliability (keandalan) yaitu kemampuan memberikan layanan yang dijanjikan dengan segera, akurat dan memuaskan. Kualitas pelayanan (service quality) yang berupa keandalan (reliability) meliputi kemampuan memberikan yang dijanjikan dengan cepat. Faktor keandalan ini jika ditingkatkan, maka akan dapat meningkatkan kepuasan pasien.

\section{Responsiveness}

Menurut Parasuraman (2008) berpendapat bahwa responsiveness yaitu keinginan para staf untuk membantu pasien dengan memberikan pelayanan dengan tanggap. Kualitas pelayanan yang berupa daya tanggap adalah staf yang memberikan pelayanan dengan tanggap, jika para staff untuk membantu para pelanggan dan memberikan pelayanan dengan tanggap, semakin tinggi kepuasan pasien.

\section{Assurance}

Menurut Parasuraman (2008) mengemukakan Assurance mencakup kemampuan, kesopanan, dan sifat yang dapat dipercaya yang dimiliki oleh staff bebas dari bahaya, resiko dan keragu-raguan, jika pengelakuan dan kemampuan dapat dipercaya yang dimiliki oleh staff karyawan ditingkatkan, maka semakin tinggi tingkat kepuasan pasien.

\section{Tangible}

Menurut Parasuraman (2008) Tangibles adalah meliputi fasilitas fisik, perlengkapan, pegawai dan sarana komunikasi. Pengaruh kualitas pelayanan terhadap kepuasan pasien mempunyai hubungan yang erat. Kualitas pelayanan adalah hasil persepsi dari perbandingan antara harapan dengan loyalitas yang diterima pasien.

\section{Empathy}

Menurut Parasuraman (2008) berpendapat bahwa Empathy adalah meliputi kemudahan dalam melakukan hubungan komunikasi yang baik, perhatian pribadi dan memahami kebutuhan pasien. 


\section{KERANGKA PEMIKIRAN}

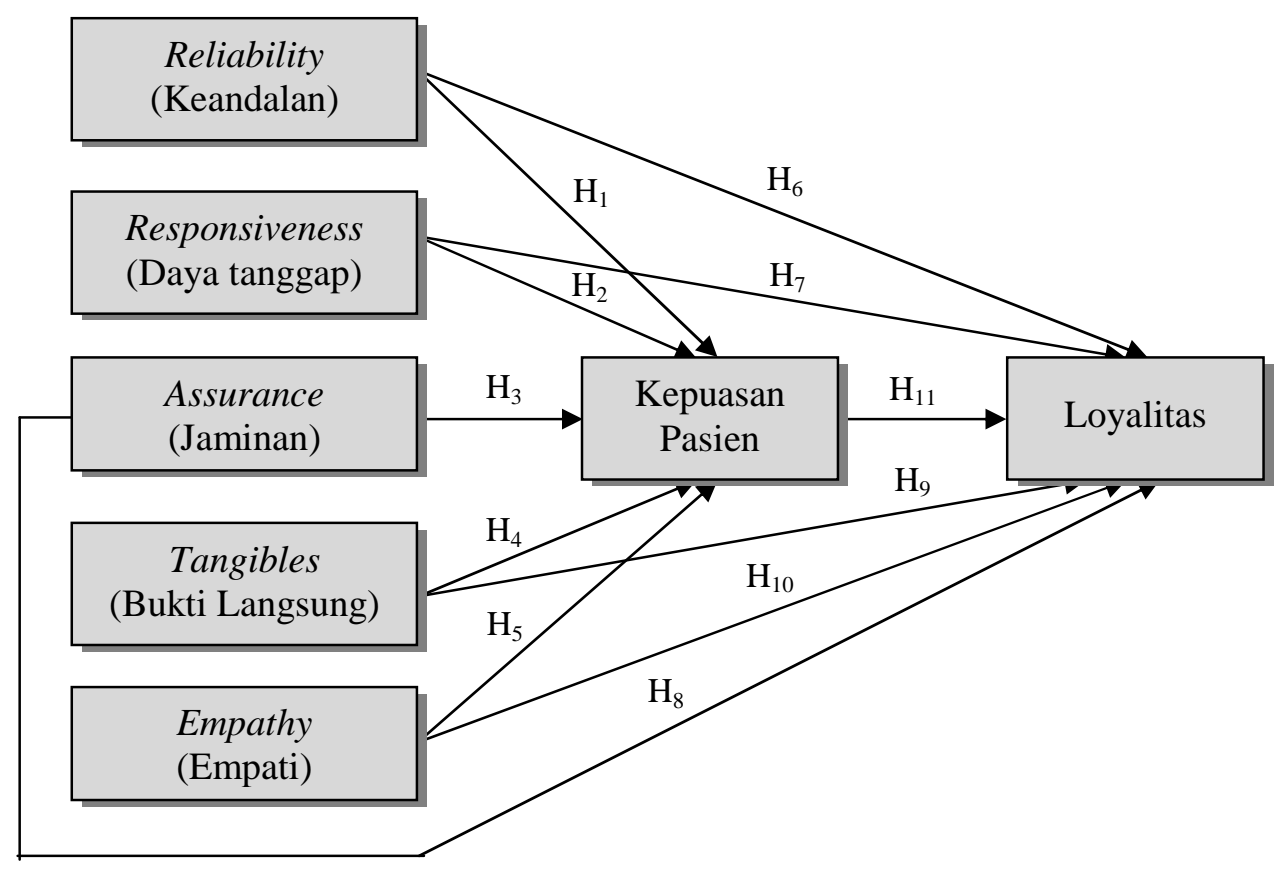

Gambar 1

Kerangka Pemikiran

\section{HIPOTESIS}

1. Reliability (keandalan) berpengaruh signifikan terhadap Kepuasan pasien pada RSU Assalam Gemolong Sragen.

2. Responsiveness (daya tanggap) berpengaruh signifikan terhadap Kepuasan pasien pada RSU Assalam Gemolong Sragen.

3. Assurance (asuransi) berpengaruh signifikan terhadap Kepuasan pasien pada RSU Assalam Gemolong Sragen.

4. Tangibles (bukti langsung) berpengaruh signifikan terhadap Kepuasan pasien pada RSU Assalam Gemolong Sragen.

5. Empathy (empati) berpengaruh signifikan terhadap Kepuasan pasien pada RSU Assalam Gemolong Sragen.

6. Reliability (keandalan) berpengaruh signifikan terhadap Loyalitas pasien pada RSU Assalam Gemolong Sragen.

7. Responsiveness (daya tanggap) berpengaruh signifikan terhadap Loyalitas pasien pada RSU Assalam Gemolong Sragen.

8. Assurance (asuransi) berpengaruh signifikan terhadap Loyalitas pasien pada RSU Assalam Gemolong Sragen.

9. Tangibles (bukti langsung) berpengaruh signifikan terhadap Loyalitas pasien pada RSU Assalam Gemolong Sragen.

10. Empathy (empati) berpengaruh signifikan terhadap Loyalitas pasien pada RSU Assalam Gemolong Sragen.

11. Kepuasan pasien berpengaruh signifikan terhadap Loyalitas pasien pada RSU Assalam Gemolong Sragen. 


\section{METODE PENELITIAN}

Penelitian ini dilakukan di Rumah Sakit Umum Assalam Gemolong Sragen. Obyek penelitian ini adalah pasien rumah sakit inap.

\section{TEKNIK ANALISIS DATA}

\section{Pengujian Instrumen}

a. Uji Validitas

$$
r_{x y}=\frac{n\left(\sum X Y\right)-\sum X \cdot \sum Y}{\sqrt{n \sum X^{2}-\left(\sum X\right)^{2}} \sqrt{n \sum Y^{2}-\left(\sum Y\right)^{2}}}
$$

Keterangan :

$\mathrm{r}_{\mathrm{xy}}=$ koefisien antara $\mathrm{x}$ dan $\mathrm{y}$

$\mathrm{x} \quad=$ skor nilai $\mathrm{x}$

$\mathrm{y} \quad=$ skor nilai total $\mathrm{y}$

$\mathrm{n} \quad=$ jumlah sampel

b. Uji Reliabilitas

$$
\mathrm{R}_{11}=\left[\frac{k}{(k-1)}\right]\left[1-\frac{\sum \sigma_{b}^{2}}{\sigma t^{2}}\right]
$$

Keterangan :

$\mathrm{R}_{11} \quad=$ reliabilitas instrument

$\mathrm{k} \quad=$ banyaknya butir pernyataan

$\Sigma \sigma_{\mathrm{b}}^{2} \quad=$ jumlah varian butir

$\sigma \mathrm{t}^{2} \quad=$ varian total

\section{Pengujian Hipotesis}

a. Uji Linieritas

Uji linieritas yang bertujuan untuk melihat linier atau tidaknya dalam distribusi sebuah data penelitian. Dari hasil yang diperolehnya akan melalui diuji linieritas menggunakan Teknik Analisis Regresi untuk digunakan mengestimasi dengan ujian linieritas yang bertujuan untuk memperoleh nilai $C^{2}$ hitung atau $\left(n \times R^{2}\right)$.

b. Analisis Regresi dengan variabel intervening (Path Analisis)

Dengan uji persemaan regresi :

Persamaan 1 :

$Y_{1}=a+\beta_{1} X_{1}+\beta_{2} X_{2}+\beta_{3} X_{3}+\beta_{4} X_{4}+\beta_{5} X_{5}+e_{1}$

Persamaan 2 :

$Y_{2}=\beta_{1} X_{1}+\beta_{2} X_{2}+\beta_{3} X_{3}+\beta_{4} X_{4}+\beta_{5} X_{5}+e_{2}$

c. Uji F

Uji F ini bertujuan untuk mengetahui pengaruh signifikansi antara semua variabel independent terhadap variabel dependent secara bersama-sama. Jika dikatakan berpengaruh signifikan apabila nilai signifikansinya $<0,05$.

d. Uji t 
Uji t ini bertujuan untuk menguji dan mengetahui apakah masing-masing variabel independent berpengaruh signifikan terhadap variabel dependent, jika dikatakan berpengaruh signifikan, apabila nilai signifikansinya $<0,05$.

e. Analisa Koefisien Determinasi $\left(\mathrm{R}^{2}\right)$

Uji Analisis Koefisien Determinasi bertujuan untuk menganalisa dan mengetahui besarnya sumbangan pengaruh variabel independent terhadap variabel dependent dinyatakan dengan rumus $\mathrm{R}^{2}$ adalah :

$$
R^{2}=\frac{B_{1} \sum Y X_{1}+B_{2} \sum X_{2}}{\sum Y_{2}}
$$

f. Analisis Korelasi

Uji Analisis Korelasi ini digunakan untuk mengetahui hubungan antara variabel independent terhadap variabel dependent. Koefisien korelasinya dapat diketahui nilai product moment dari Pearson. Jika nilai signifikansi $\langle\alpha=0,05$ terdapat hubungan yang signifikansi dan jika nilai signifikansinya $>\alpha=0,05$, maka tidak ada hubungan.

\section{HASIL ANALISIS}

1.

\section{Uji Validitas}

a.

Validitas item pertanyaan untuk variabel Reliability $\left(\mathrm{X}_{1}\right)$

Tabel 1

Korelasi Item Pertanyaan Terhadap Variabel Reliability

\begin{tabular}{crrc}
\hline Item Pertanyaan & \multicolumn{1}{r}{$\mathrm{r}_{\text {item }}$} & $\mathrm{r}_{\text {tabel }}$ & Keterangan \\
\hline x1_1 & 0,806 & 0,157 & Valid \\
x1_2 & 0,762 & 0,157 & Valid \\
x1_3 & 0,771 & 0,157 & Valid \\
x1_4 & 0,836 & 0,157 & Valid \\
x1_5 & 0,762 & 0,157 & Valid \\
x1_6 & 0,810 & 0,157 & Valid \\
\hline
\end{tabular}

Sumber : Data yang diolah, 2011

Tabel 1 diatas menunjukkan bahwa dari 6 item pertanyaan semua valid.

b. $\quad$ Validitas item pertanyaan untuk variabel Responsiveness $\left(\mathrm{X}_{2}\right)$

Tabel 2

Korelasi Item Pertanyaan Terhadap Variabel Responsiveness

\begin{tabular}{crcc}
\hline Item Pertanyaan & \multicolumn{1}{c}{$\mathrm{r}_{\text {item }}$} & $\mathrm{r}_{\text {tabel }}$ & Keterangan \\
\hline x2_1 & 0,650 & 0,157 & Valid \\
x2_2 & 0,715 & 0,157 & Valid \\
x2_3 & 0,759 & 0,157 & Valid \\
x2_4 & 0,847 & 0,157 & Valid \\
x2_5 & 0,817 & 0,157 & Valid \\
x2_6 & 0,852 & 0,157 & Valid \\
\hline
\end{tabular}

Sumber : Data yang diolah, 2011

Tabel 2 diatas menunjukkan bahwa dari 6 item pertanyaan semua valid. 
c. Validitas item pertanyaan untuk variabel Assurance $\left(\mathrm{X}_{3}\right)$

Tabel 3

Korelasi Item Pertanyaan Terhadap Variabel Assurance

\begin{tabular}{crcc}
\hline Item Pertanyaan & \multicolumn{1}{c}{$\mathrm{r}_{\text {item }}$} & $\mathrm{r}_{\text {tabel }}$ & Keterangan \\
\hline x3_1 & 0,806 & 0,157 & Valid \\
x3_2 & 0,746 & 0,157 & Valid \\
x3_3 & 0,707 & 0,157 & Valid \\
x3_4 & 0,825 & 0,157 & Valid \\
x3_5 & 0,857 & 0,157 & Valid \\
x3_6 & 0,804 & 0,157 & Valid \\
\hline
\end{tabular}

Sumber : Data yang diolah, 2011

Tabel 3 diatas menunjukkan bahwa dari 6 item pertanyaan semua valid.

d. Validitas item pertanyaan untuk variabel Tangibles $\left(\mathrm{X}_{4}\right)$

Tabel 4

Korelasi Item Pertanyaan Terhadap VariabelTangibles

\begin{tabular}{crrc}
\hline Item Pertanyaan & \multicolumn{1}{c}{$\mathrm{r}_{\text {item }}$} & $\mathrm{r}_{\text {tabel }}$ & Keterangan \\
\hline x4_1 & 0,755 & 0,157 & Valid \\
x4_2 & 0,855 & 0,157 & Valid \\
x4_3 & 0,840 & 0,157 & Valid \\
x4_4 & 0,828 & 0,157 & Valid \\
x4_5 & 0,806 & 0,157 & Valid \\
x4_6 & 0,823 & 0,157 & Valid \\
\hline
\end{tabular}

Sumber : Data yang diolah, 2011

Tabel 4 diatas menunjukkan bahwa dari 6 item pertanyaan semua valid.

e. Validitas item pertanyaan untuk variabel Empathy $\left(\mathrm{X}_{5}\right)$

Tabel 5

Korelasi Item Pertanyaan Terhadap Variabel Empathy

\begin{tabular}{crrc}
\hline Item Pertanyaan & \multicolumn{1}{c}{$\mathrm{r}_{\text {item }}$} & $\mathrm{r}_{\text {tabel }}$ & Keterangan \\
\hline x5_1 & 0,764 & 0,157 & Valid \\
x5_2 & 0,785 & 0,157 & Valid \\
x5_3 & 0,824 & 0,157 & Valid \\
x5_4 & 0,689 & 0,157 & Valid \\
x5_5 & 0,813 & 0,157 & Valid \\
x5_6 & 0,157 & Valid \\
\hline
\end{tabular}

Sumber : Data yang diolah, 2011

Tabel 5 diatas menunjukkan bahwa dari 6 item pertanyaan semua valid.

f. Validitas item pertanyaan untuk variabel Kepuasan $\left(\mathrm{Y}_{1}\right)$

Tabel 6

Korelasi Item Pertanyaan Terhadap Variabel Kepuasan 


\begin{tabular}{crcc}
\hline Item Pertanyaan & \multicolumn{1}{c}{$\mathrm{r}_{\text {item }}$} & $\mathrm{r}_{\text {tabel }}$ & Keterangan \\
\hline $\mathrm{y} 1 \_1$ & 0,755 & 0,157 & Valid \\
y1_2 & 0,787 & 0,157 & Valid \\
y1_3 & 0,620 & 0,157 & Valid \\
y1_4 & 0,835 & 0,157 & Valid \\
y1_5 & 0,889 & 0,157 & Valid \\
y1_6 & 0,865 & 0,157 & Valid \\
\hline
\end{tabular}

Sumber : Data yang diolah, 2011

Tabel 6 diatas menunjukkan bahwa dari 6 item pertanyaan semua valid.

g. Validitas item pertanyaan untuk variabel Loyalitas $\left(\mathrm{Y}_{2}\right)$

Tabel 7

Korelasi Item Pertanyaan Terhadap Variabel Loyalitas

\begin{tabular}{crcc}
\hline Item Pertanyaan & \multicolumn{1}{c}{$\mathrm{r}_{\text {item }}$} & $\mathrm{r}_{\text {tabel }}$ & Keterangan \\
\hline y2_1 & 0,812 & 0,157 & Valid \\
y2_2 & 0,860 & 0,157 & Valid \\
y2_3 & 0,807 & 0,157 & Valid \\
y2_4 & 0,695 & 0,157 & Valid \\
y2_5 & 0,893 & 0,157 & Valid \\
y2_6 & 0,830 & 0,157 & Valid \\
\hline
\end{tabular}

Sumber : Data yang diolah, 2011

Tabel 7 diatas menunjukkan bahwa dari 6 item pertanyaan semua valid.

\section{Uji Reliabilitas Data}

Tabel 8

Hasil Uji Reliabilitas

\begin{tabular}{lccc}
\hline \multicolumn{1}{c}{ Variabel } & Alpha Cronbach & Kriteria & Keterangan \\
\hline Reliability & 0,928 & Alpha Cronbach> & Reliabel \\
Responsiveness & 0,920 & 0,60 maka & Reliabel \\
Assurance & 0,927 & reliable & Reliabel \\
Tangible & 0,938 & & Reliabel \\
Empathy & 0,911 & & Reliabel \\
Kepuasan & 0,926 & & Reliabel \\
Loyalitas & 0,937 & & Reliabel \\
\hline Sumber : Data yang diolah, 2010 & &
\end{tabular}

Hasil uji reliabilitas data seperti tabel di atas menunjukkan bahwa semua instrumen yang digunakan dalam penelitian ini reliabel. Hal ini ditunjukkan dengan koefisien alpha yang melebihi 0,60 . 


\section{Uji Linieritas}

Tabel 9

Hasil Uji Linieritas

\begin{tabular}{|c|c|c|c|c|}
\hline \multicolumn{5}{|c|}{ Model Summary ${ }^{\mathrm{b}}$} \\
\hline Model & $\mathrm{R}$ & R Square & $\begin{array}{l}\text { Adjusted } \\
\text { R Square }\end{array}$ & $\begin{array}{l}\text { Std. Error of } \\
\text { the Estimate }\end{array}$ \\
\hline 1 &, $046^{a}$ & ,002 &,- 062 & 1,48773939 \\
\hline
\end{tabular}

a. Predictors: (Constant), Kepuasan, Tangibles,

Responsiveness, Empathym, Reliability, Assurance

b. Dependent Variable: Unstandardized Residual

Dari tabel di atas menunjukkan nilai $\mathrm{R}^{2}$ sebesar 0,02 dengan jumlah sampel 100 besarnya nilai $c^{2}$ hitung $=100 \times 0,002=0,02$ sedangkan nilai $c^{2}$ tabel sebesar 129,56. Nilai $c^{2}$ hitung $<c^{2}$ tabel, jadi dapat disimpulkan bahwa model yang benar adalah model linier.

\section{Pengujian Hipotesis}

Hasil pengujian hipotesis yang telah dilakukan dengankomputer program SPSS Release 12 nampak sebagai berikut ini.

\section{a. Persamaan Regresi Jalur}

Model Regresi Jalur 1

Tabel 10

Hasil Persamaan Regresi Jalur 1

\section{Coofficients $^{a}$}

\begin{tabular}{|c|c|c|c|c|c|}
\hline \multirow[b]{2}{*}{ Model } & \multicolumn{2}{|c|}{$\begin{array}{c}\text { Unstandar } \\
\text { dized } \\
\text { Coefficient } \\
\text { s }\end{array}$} & \multirow{2}{*}{\begin{tabular}{|c|}
$\begin{array}{c}\text { Standardi } \\
\text { zed } \\
\text { Coefficien } \\
\text { ts }\end{array}$ \\
Beta
\end{tabular}} & \multirow[b]{2}{*}{$\mathrm{t}$} & \multirow[b]{2}{*}{ Sig. } \\
\hline & $\mathrm{B}$ & $\begin{array}{l}\text { Std. } \\
\text { Error }\end{array}$ & & & \\
\hline \multirow[t]{2}{*}{1 (Constant) } & 1,1 & 1,61 & & ,72 & ,469 \\
\hline & 72 & 0 & & 8 & \\
\hline \multirow[t]{2}{*}{ Reliability } & ,22 & ,079 & ,261 & 2,8 & ,005 \\
\hline & 8 & & & 73 & \\
\hline Responsiven & - & ,084 &,- 047 &,- & ,583 \\
\hline \multirow{2}{*}{ ess } & ,04 & & & 552 & \\
\hline & 6 & & & & \\
\hline \multirow[t]{2}{*}{ Assurance } & ,24 & ,115 & ,213 & 2,0 & ,040 \\
\hline & 0 & & & 87 & \\
\hline \multirow[t]{2}{*}{ Tangibles } & ,05 & ,053 & ,086 & 1,0 & 279 \\
\hline & 8 & & & 88 & \\
\hline \multirow[t]{2}{*}{ Empathy } & ,56 &, 114 & ,439 & 4,9 & ,000 \\
\hline & 6 & & & 58 & \\
\hline
\end{tabular}

a. Dependen Variable : Kepuasan 
Dari tabel di atas dapat dirumuskan model regresi dalam penelitian ini adalah sebagai berikut :

$$
\begin{gathered}
Y_{1}=1,172+0,261 X_{1}-0,047 X_{2}+0,213 X_{3}+0,086 X_{4}+0,439 X_{5}+\epsilon \\
(0,469)(0,005)^{* *}(0,583)(0,040)^{* *}(0,279)(0,000)^{* *}
\end{gathered}
$$

Model Regresi Jalur 2

Tabel 11

Hasil Persamaan Regresi Jalur 2

\begin{tabular}{|c|c|c|c|c|c|}
\hline \multirow[b]{2}{*}{ Model } & \multicolumn{2}{|c|}{$\begin{array}{l}\text { Unstandar } \\
\text { dized } \\
\text { Coefficient } \\
\text { s }\end{array}$} & \multirow{2}{*}{\begin{tabular}{|c|}
$\begin{array}{c}\text { Standardi } \\
\text { zed } \\
\text { Coefficien } \\
\text { ts }\end{array}$ \\
Beta \\
\end{tabular}} & \multirow[b]{2}{*}{$\mathrm{t}$} & \multirow[b]{2}{*}{ Sig. } \\
\hline & $B$ & $\begin{array}{l}\text { Std. } \\
\text { Error }\end{array}$ & & & \\
\hline \multirow{3}{*}{1 (Constant) } & - & 1,32 & & - &, 000 \\
\hline & 6,3 & 4 & & 4,7 & \\
\hline & 51 & & & 97 & \\
\hline \multirow[t]{2}{*}{ Reliability } & ,14 & ,068 & , 136 & 2,0 & ,039 \\
\hline & 2 & & & 91 & \\
\hline Responsiven & ,01 & ,069 & ,010 &, 16 & ,869 \\
\hline ess & 1 & & & 6 & \\
\hline \multirow[t]{2}{*}{ Assurance } & ,21 & 097 & , 156 & 2,1 & 031 \\
\hline & 1 & & & 89 & \\
\hline \multirow[t]{2}{*}{ Tangibles } & ,14 & ,044 & ,179 & 3,2 & ,001 \\
\hline & 5 & & & 83 & \\
\hline \multirow[t]{2}{*}{ Empathy } & ,28 & , 105 & , 184 & 2,7 & ,008 \\
\hline & 5 & & & 09 & \\
\hline \multirow[t]{2}{*}{ Kepuasan } & ,46 & ,085 & ,390 & 5,5 & ,000 \\
\hline & 7 & & & 26 & \\
\hline
\end{tabular}

\section{Coofficients $^{\mathrm{a}}$}

Dari tabel di atas dapat dirumuskan model regresi dalam penelitian ini adalah sebagai berikut :

$$
\begin{gathered}
Y_{2}=-6,351+0,136 X_{1}+0,010 X_{2}+0,156 X_{3}+0,179 X_{4}+0,184 X_{5}+0,390 X_{6}+\epsilon \\
(0,000)^{* *}(0,039)^{* *}(0,869)(0,031)^{* *}(0,001)^{* *}(0,008)^{* *}(0,000)^{* *}
\end{gathered}
$$

\section{b. Uji Statistik t}

Pengujian dalam penelitian ini dilakukan dengan bantuan komputer dengan program SPSS Versi 15, dengan taraf signifikansi 5\% dan jumlah responden sebanyak 100 orang. Berdasarkan hasil analisis yang dilakukan seperti tabel di atas dapat dijelaskan hal-hal berikut : 1) Uji Hipotesis Model 1

a) Pengaruh reliability terhadap kepuasan pasien rawat inap di RSU Assalam Gemolong 
Hasil pengujian yang dilakukan menunjukkan untuk variabel reliability mempunyai nilai signifikansi $0,005<0,05$ artinya variabel reliability mempunyai pengaruh secara signifikan terhadap kepuasan pasien. Kesimpulan dari pengujian ini hipotesis terbukti.

b) Pengaruh responsiveness terhadap kepuasan pasien rawat inap di RSU Assalam Gemolong

Hasil pengujian yang dilakukan menunjukkan untuk variabel responsiveness mempunyai nilai signifikansi 0,583 $>0,05$ artinya variabel responsiveness mempunyai pengaruh negatif tetapi tidak signifikan terhadap kepuasan pasien. Kesimpulan dari pengujian ini hipotesis tidak terbukti.

c) Pengaruh assurance terhadap kepuasan pasien rawat inap di RSU Assalam Gemolong Hasil pengujian yang dilakukan menunjukkan untuk variabel assurance mempunyai nilai signifikansi $0,040<0,05$ artinya variabel assurance mempunyai pengaruh secara signifikan terhadap kepuasan pasien. Kesimpulan dari pengujian ini hipotesis terbukti.

d) Pengaruh tangible terhadap kepuasan pasien rawat inap di RSU Assalam Gemolong Hasil pengujian yang dilakukan menunjukkan untuk variabel tangible mempunyai nilai signifikansi 0,279>0,05 artinya variabel tangible berpengaruh tidak signifikan terhadap kepuasan pasien. Kesimpulan dari pengujian ini hipotesis tidak terbukti.

e) Pengaruh empathy terhadap kepuasan pasien rawat inap di RSU Assalam Gemolong Hasil pengujian yang dilakukan menunjukkan untuk variabel empathy mempunyai nilai signifikansi $0,000<0,05$ artinya variabel empathy mempunyai pengaruh signifikan terhadap kepuasan pasien. Kesimpulan dari pengujian ini hipotesis terbukti.

2) Uji Hipotesis Model 2

a) Pengaruh reliability terhadap loyalitas pasien rawat inap di RSU Assalam Gemolong Hasil pengujian yang dilakukan menunjukkan untuk variabel reliability mempunyai nilai signifikansi $0,039<0,05$ artinya variabel reliability mempunyai pengaruh secara signifikan terhadap loyalitas pasien. Kesimpulan dari pengujian ini hipotesis terbukti.

b) Pengaruh responsiveness terhadap loyalitas pasien rawat inap di RSU Assalam Gemolong

Hasil pengujian yang dilakukan menunjukkan untuk variabel responsiveness mempunyai nilai signifikansi 0,869>0,05 artinya variabel responsivenessberpengaruh tidak signifikan terhadap loyalitas pasien. Kesimpulan dari pengujian ini hipotesis tidak terbukti.

c) Pengaruh assurance terhadap loyalitas pasien rawat inap di RSU Assalam Gemolong Hasil pengujian yang dilakukan menunjukkan untuk variabel assurance mempunyai nilai signifikansi $0,031<0,05$ artinya variabel assurance mempunyai pengaruh secara signifikan terhadap loyalitas pasien. Kesimpulan dari pengujian ini hipotesis terbukti.

d) Pengaruh tangible terhadap loyalitas pasien rawat inap di RSU Assalam Gemolong Hasil pengujian yang dilakukan menunjukkan untuk variabel tangible mempunyai nilai signifikansi $0,008<0,05$ artinya variabel tangiblemempunyai pengaruhsignifikan terhadap loyalitas pasien. Kesimpulan dari pengujian ini hipotesis terbukti.

e) Pengaruh empathy terhadap loyalitas pasien rawat inap di RSU Assalam Gemolong Hasil pengujian yang dilakukan menunjukkan untuk variabel empathy mempunyai nilai signifikansi $0,001<0,05$ artinya variabel empathy mempunyai pengaruh signifikan terhadap loyalitas pasien. Kesimpulan dari pengujian ini hipotesis terbukti.

f) Pengaruh kepuasan terhadap loyalitas pasien rawat inap di RSU Assalam Gemolong Hasil pengujian yang dilakukan menunjukkan untuk variabel kepuasan mempunyai nilai signifikansi $0,000<0,05$ artinya variabel kepuasan mempunyai pengaruh secara signifikan terhadap loyalitas pasien. Kesimpulan dari pengujian ini hipotesis terbukti. 


\section{c. Uji Statistik F}

Tabel 12

Hasil Uji F

ANOVA $^{\mathrm{b}}$

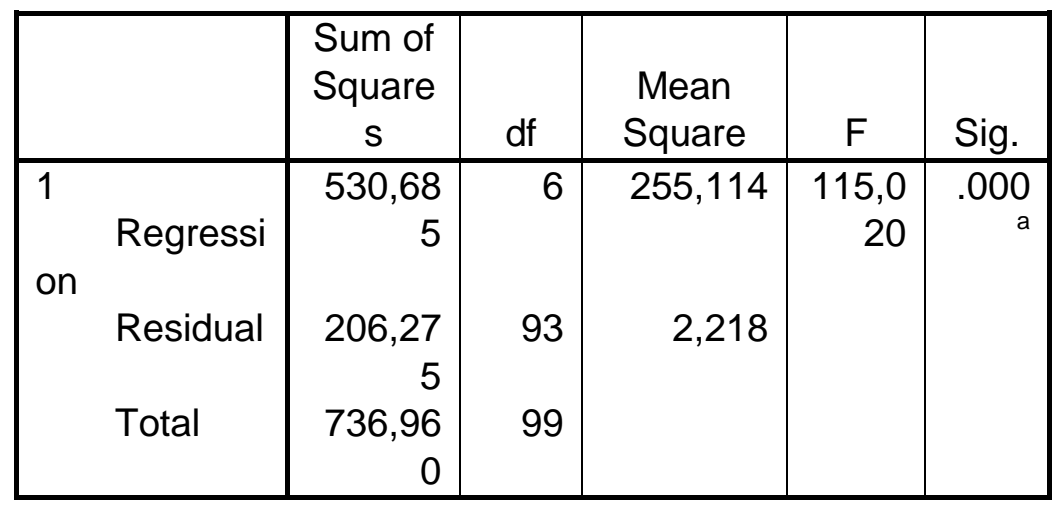

a. Predictors: (Constant), Kepuasan, Tangibles, Responsiveness, Reliability, Empathy, Assurance

b. Dependent Variable: Loyalitas

Nilai $\mathrm{F}$ hitung pada tabel tersebut di atas menunjukkan bahwa kelima variabel yaitu reliability, responsiveness, assurance, tangible, dan empathy secara bersama-sama berpengaruh signifikan terhadap kepuasan pasien rawat inap. Hal ini didukung dengan nilai F hitung sebesar 115,020 dengan nilai signifikansinya sebesar 0,000 $<0,05$. Kesimpulannya hipotesis terbukti.

d. Koefisien Determinasi $\left(\mathbf{R}^{2}\right)$

1) Koefisien Determinasi Persamaan 1

Tabel 13

Hasil Koefisien Determinasi Persamaan 1

\begin{tabular}{|c|c|c|c|c|}
\hline \multicolumn{5}{|c|}{ Model Summary ${ }^{\mathrm{b}}$} \\
\hline Model & $\mathrm{R}$ & R Square & $\begin{array}{l}\text { Adjusted } \\
\text { R Square }\end{array}$ & $\begin{array}{l}\text { Std. Error of } \\
\text { the Estimate }\end{array}$ \\
\hline 1 &, $862^{a}$ & ,744 & ,730 & 1,816 \\
\hline
\end{tabular}

a. Predictors: (Constant), Empathy, Tangibles,

Responsiveness, Reliability, Assurance

b. Dependent Variable: Kepuasan

$$
\begin{aligned}
& e_{1}=\sqrt{1-R_{1}^{2}} \\
& e_{1}=\sqrt{1-0,744} \\
& e_{1}=0,34
\end{aligned}
$$

2) Koefisien Determinasi Persamaan 2 
Tabel 14

Hasil Koefisien Determinasi Persamaan 2

Model Summary
\begin{tabular}{|l|r|r|r|c|}
\hline Model & R & R Square & $\begin{array}{l}\text { Adjusted } \\
\text { R Square }\end{array}$ & $\begin{array}{c}\text { Std. Error of } \\
\text { the Estimate }\end{array}$ \\
\hline 1 &, $939^{\mathrm{a}}$ &, 881 &, 874 & 1,489 \\
\hline
\end{tabular}

a. Predictors: (Constant), Kepuasan, Tangibles,

Responsiveness, Reliability, Empathy, Assurance

b. Dependent Variable: Loyalitas

$$
\begin{aligned}
& e_{2}=\sqrt{1-R_{1}^{2}} \\
& e_{2}=\sqrt{1-0,881} \\
& e_{2}=0,34
\end{aligned}
$$

Maka nilai koefisien determinasi $\left(\mathrm{R}^{2}\right)=$

$$
\begin{aligned}
\mathrm{R}^{2} & =1-\left(\mathrm{e}_{1} \mathrm{x}_{\mathrm{e}} 2\right) \\
\mathrm{R}^{2} & =1-\left((0,50)^{2} \times(0,34)^{2}\right) \\
& =1-(0,250 \times 0,116)
\end{aligned}
$$

Nilai R square total sebesar 0,971 artinya loyalitas dijelaskan oleh dimensi kualitas pelayan dengan kepuasan sebagai variabel intervening sebesar $97,1 \%$ dan sisanya sebesar $2,9 \%$ dijelaskan variabel lain di luar model penelitian, misalnya variabel lokasi dan harga.

\section{e. Pengaruh Langsung, Pengaruh Tidak Langsung dan Pengaruh Total}

Hasil uji untuk menggambarkan pengaruh variabel independen terhadap dependen baik langsung, tidak langsung dan total pengaruh dapat disusun struktur sebagai berikut :

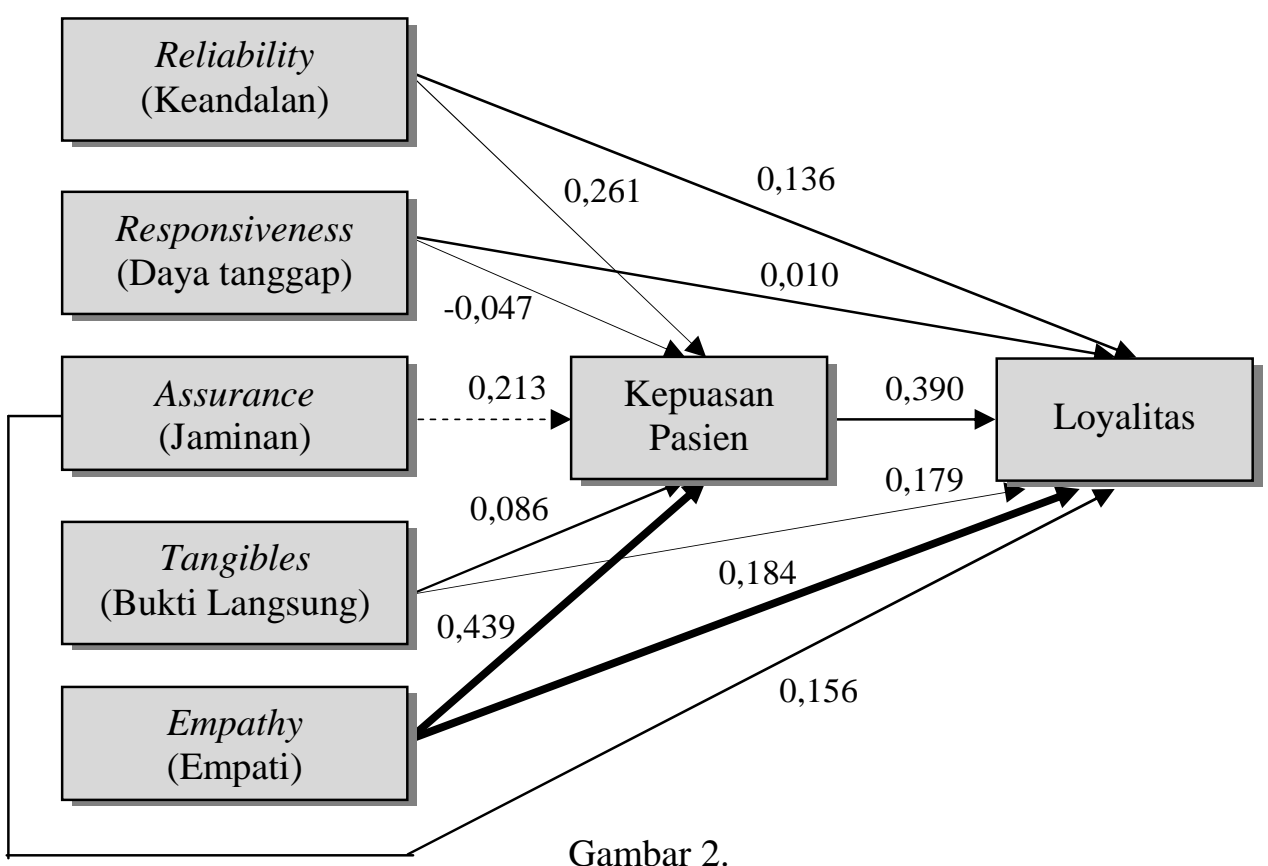

Pengaruh langsung, pengaruh tidaklangsung, dan pengaruh total 
Tabel 15

Pengaruh antara variabel langsung, tidak langsung dan total

\begin{tabular}{|c|c|c|c|c|}
\hline & Pengaruh & Langsung & Tidak Langsung & Total \\
\hline Jalur 1 & $\begin{array}{l}\text { Reliability } \rightarrow \text { kepuasan } \\
\text { Responsiveness } \rightarrow \\
\text { kepuasan } \\
\text { Assurance } \rightarrow \text { kepuasan } \\
\text { Tangible } \rightarrow \text { kepuasan } \\
\text { Empathy } \rightarrow \text { kepuasan }\end{array}$ & $\begin{array}{r}0,261 \\
-0,047 \\
0,213 \\
0,086 \\
0,439\end{array}$ & & \\
\hline Jalur 2 & $\begin{array}{l}\text { Reliability } \rightarrow \text { loyalitas } \\
\text { Responsiveness } \rightarrow \\
\text { loyalitas } \\
\text { Assurance } \rightarrow \text { loyalitas } \\
\text { Tangible } \rightarrow \text { loyalitas } \\
\text { Empathy } \rightarrow \text { loyalitas } \\
\text { Kepuasan } \rightarrow \text { loyalitas }\end{array}$ & & $\begin{array}{l}0,136 \times 0,390= \\
0,053 \\
0,010 \times 0,390= \\
0,004 \\
0,156 \times 0,390= \\
0,061 \\
0,179 \times 0,390= \\
0,070 \\
0,184 \times 0,390= \\
0,072 \\
0,390\end{array}$ & \\
\hline & $\begin{array}{l}\text { Reliability } \rightarrow \text { kepuasan } \rightarrow \\
\text { loyalitas } \\
\text { Responsiveness } \rightarrow \\
\text { kepuasan } \rightarrow \text { loyalitas } \\
\text { Assurance } \rightarrow \text { kepuasan } \rightarrow \\
\text { loyalitas } \\
\text { Tangible } \rightarrow \text { kepuasan } \rightarrow \\
\text { loyalitas } \\
\text { Empathy } \rightarrow \text { kepuasan } \rightarrow \\
\text { loyalitas }\end{array}$ & & & $\begin{array}{l}0,136+ \\
0,101 \\
0,237 \\
0,010+ \\
0,0180,028 \\
0,156+ \\
0,083 \\
0,238 \\
0,174+ \\
0,033 \\
0,212 \\
0,184+ \\
0,171 \\
0,355 \\
\end{array}$ \\
\hline
\end{tabular}

Sumber : Data primer diolah, 2011 


\section{KESIMPULAN}

1. Secara individual pengujian terhadap hipotesis penelitian menunjukkan bahwa :

a. Reliability mempunyai pengaruh signifikan terhadap Kepuasan pasien rawat inap di RSU Assalam Gemolong Sragen.

b. Responsiveness mempunyai pengaruh signifikan terhadap Kepuasan pasien rawat inap di RSU Assalam Gemolong Sragen.

c. Assurance mempunyai pengaruh signifikan terhadap Kepuasan pasien rawat inap di RSU Assalam Gemolong Sragen.

d. Tangible mempunyai pengaruh signifikan terhadap Kepuasan pasien rawat inap di RSU Assalam Gemolong Sragen.

e. Empathy mempunyai pengaruh signifikan terhadap Kepuasan pasien rawat inap di RSU Assalam Gemolong Sragen.

f. Kepuasan mempunyai pengaruh signifikan terhadap Loyalitas pasien rawat inap di RSU Assalam Gemolong Sragen

2. Secara simultan terdapat pengaruh yang signifikan antara variabel independent yang terdiri dari Reliability, Responsiveness, Assurance, Tangible, dan Empathy terhadap Loyalitas pasien rawat inap di RSU Assalam Gemolong Sragen.

3. Nilai $\mathrm{R}^{2}$ didapatkan hasil sebesar 0,971 artinya Loyalitas dijelaskan oleh dimensi kualitas pelayanan dengan Kepuasan sebagai variabel intervening sebesar 97,1\% dan sisanya sebesar 2,9\% dijelaskan oleh variabel lain misalnya lokasi.

\section{DAFTAR PUSTAKA}

Arikunto, Suharsimi, 2004, Prosedur Penelitian Suatu Pendekatan Praktek, Rineka Cipta, Jakarta.

Basu Swastha dan Irawan, 2011, Manajemen Pemasaran Modern, Liberty, Yogyakarta.

Darmesta Basu Swastha, 2009, Loyalitas Pelanggan, Sebuah Kajian Konseptual sebagai Panduan bagi Peneliti, Jurnal Ekonomi dan Bisnis Indonesia, Vol.4, No.3.

Fornell, C. J.D. Michael, A.W. Eugene, C Jaesung and B.E Barbara., 1996, "The American Customer Satisfaction Index : Natural, Purpose and Finding”, Journal of Marketing, Vol.60, October, P.\&-18.

Griffin Jill, (2010), Customer Loyalty, Erlangga, Jakarta.

Handayani, 2006, Pengaruh Faktor Kualitas Pelayanan terhadap Kepuasan dan Dampaknya pada Loyalitas Nasabah BNI Taplus pada BNI 46 Kantor Cabang UNAIR Surabaya.

Handriana, T., 2002, “Analisis Perbedaan Harapan Kualitas Pelayanan pada Lembaga Pendidikan Tinggi di Surabaya”, Tesis, Yogyakarta: Program Pasca Sarjana UGM.

Hapsari Indri, 2007, Pengaruh Persepsi Kualitas Layanan terhadap Kepuasan Konsumen Internet Service Provider Idolanet Jenis Personal Dial Up di Surabaya.

Kotler, Philip., 2006, Marketing Management : Analysis, Planning, Implementations, and Control, 9 Th Ed Engle Wood Cliffs, N.J : Prentice Hall International, Inc.

Kotler, Philip., 2007, Marketing Management : Analysis, Planning, Implementations, and Control, (Terjemahan) 9 Th Ed Engle Wood.

Lupiyoadi R. \& Hamdani A., 2011, Manajemen Pemasaran Jasa, Jakarta, Salemba Empat.

Oliver, Richard L., 2010, Satisfaction : A Behavioral Perspective an the Customer, Mc. Grow Hill, New York, NY.

Palilati Alida, 2009, Pengaruh Nilai Pelanggan, Kepuasan terhadap Loyalitas Nasabah Tabungan Perbankan di Sulawesi Selatan. 
Parasuraman, A., V.A Zeithaml, and L.L Berry., 1988, "SERVQUAL : A Multiple Item Scale For Measuring Customer Perceptions of Service Quality”, Journal of Retailing, Vol. 64 (1) P. 12-40.

Sarwono, 2009, Pengaruh Dimensi Kualitas Jasa terhadap Kepuasan Anggota Koperasi pada Koperasi Kopendik di Wonogiri.

Tjiptono Fandi, 2006, Strategi Pemasaran, Andi Offset, Yogyakarta.

Tjiptono Fandi,m 2011, Manajemen Jasa, Andi Offset, Yogyakarta.

Tjiptono, Fandi, 1996. Manajemen Jasa, Yogyakarta: Penerbit Andi.

Tjiptono, Fandi, 1997, Prinsip-prinsip Total Quality Service, Yogyakarta: Penerbit Andi.

Tjiptono, Fandi, 2002, Prinsip-prinsip Total Quality Service, Yogyakarta: Penerbit Andi.

Wasi, 2010, Pengaruh Kualitas Pelayanan terhadap Kepuasan Nasabah dan Loyalitas Nasabah di AJB Bumi Putra 1912 Kantor Cabang Wonogiri.

Zeithaml V.A., Berry L.L. \& Parasuraman A., 2008, The Behavioral Cunsequences of Service Quality. Jurnal of Marketing 60. 